\title{
Effect of Nelumbo nucifera Petal Extracts on Lipase, Adipogenesis, Adipolysis, and Central Receptors of Obesity
}

\author{
Chandrasekaran Chinampudur Velusami, ${ }^{1,2}$ \\ Amit Agarwal, ${ }^{1}$ and Vijayalakshmi Mookambeswaran ${ }^{2}$ \\ ${ }^{1}$ R\&D Centre, Natural Remedies Pvt. Ltd., Plot No. 5B, Veerasandra Industrial Area, 19th K.M. Stone, Hosur Road, Bangalore, \\ Karnataka 560100, India \\ ${ }^{2}$ Center for Bioseparation Technology, VIT University, Vellore, Tamil Nadu 632014, India
}

Correspondence should be addressed to Chandrasekaran Chinampudur Velusami; cvc@naturalremedy.com

Received 22 July 2013; Revised 30 September 2013; Accepted 2 October 2013

Academic Editor: C. S. Cho

Copyright (c) 2013 Chandrasekaran Chinampudur Velusami et al. This is an open access article distributed under the Creative Commons Attribution License, which permits unrestricted use, distribution, and reproduction in any medium, provided the original work is properly cited.

\begin{abstract}
N. nucifera is one among the important medicinal plants assessed for its antiobesity action in various preclinical models. The present study was aimed at investigating the antiobesity effect of methanol and successive water extracts of petals of $N$. nucifera by studying its effect on adipogenesis, adipolysis, lipase, serotonin $\left(5-\mathrm{HT}_{2 \mathrm{C}}\right)$, cannabinoid $\left(\mathrm{CNR}_{2}\right)$, melanocyte concentrating hormone $\left(\mathrm{MCHR}_{1}\right)$, and melanocortin $\left(\mathrm{MC}_{4} \mathrm{R}\right)$ receptors. Both methanol and successive water extracts of $N$. nucifera petals had an effect on inhibition of lipid storage in adipocytes and on increasing lipolysis. N. nucifera petal methanol extract exhibited the concentrationdependent inhibitory effect on lipase activity with an $\mathrm{IC}_{50}$ value of $47 \mu \mathrm{g} / \mathrm{mL}$. N. nucifera petal extracts showed evident agonist and antagonist activity towards $5-\mathrm{HT}_{2 \mathrm{C}}$ and $\mathrm{CNR}_{2}$ receptors, respectively, while it showed no effect towards $\mathrm{MCHR}_{1}$ and $\mathrm{MC}_{4} \mathrm{R}$ receptors. Overall, methanol extract of $N$. nucifera petals showed better activity than successive water extract.
\end{abstract}

\section{Introduction}

Several herbs have been indicated for weight management [1]. One such plant used for weight management is Nelumbo nucifera Gaertn. N. nucifera, known by a number of names including Indian lotus, sacred lotus, bean of India, or simply lotus, is one of two species of aquatic plant in the family Nelumbonaceae. Almost all parts of N. nucifera are edible, and in many Asian countries it was found in the recipe of food [2]. Extracts of N. nucifera flowers, seeds, rhizomes, and leaves have been reported to have varied therapeutic potential including antistress [3], antiobesity [4], antioxidant [5], hepatoprotective [6], antidiabetic activity [7], antiinflammatory $[8,9]$, antipyretic [10], antibacterial [11], and immunomodulatory $[12,13]$ activities.

Several bioactive phytocompounds derived from these plant parts were belonging to different chemical groups, including alkaloids, flavonoids, glycosides, triterpenoid, and vitamins [14]. Leaves, root, and the embryonic stage of $N$. nucifera have been reported to contain alkaloids such as roemerine, nuciferine, nornuciferine, nelumboside, anonaine, 5-methoxy-6-hydroxyaporphine, liensinine, and asimilobine [15]. Bisbenzylisoquinoline alkaloids from $N$. nucifera were shown to be bioavailable after oral administration to rats at a dose of $20 \mathrm{mg} / \mathrm{kg}$ [16]. N. nucifera alkaloid was shown to inhibit 3T3-L1 preadipocyte differentiation and improve high-fat diet-induced obesity and body fat accumulation in rats [17].

Several flavonoids and nonflavonoids from flowers of $N$. nucifera reported by several authors were consolidated in a review by Mukherjee et al. [14]. Flavonoids include myricetin3-O-b-D-glucopyranoside, quercetin-3-O-b-D-glucuronide, astragalin, quercetin, 3,4-dihydroxybenzoic, kaempferol, phydroxybenzoic acid, and b-sitosterol which were isolated from ethanol extract of the petals of $N$. nucifera [18]. Nonflavonoid compounds, including adenine, myo-inositol, arbutin, and sitosterol glucopyranoside, were identified in flower extract [14]. Wu et al. [19] demonstrated the antiobesity effect of a flavonoid-enriched extract from $N$. nucifera leaf (NLFE) in high-fat diet (HFD) fed C57BL/6 mice and 
concluded its action via lipid-regulated enzymes, thereby attenuating body lipid accumulation and preventing obesity. Antiobesity action of leaves and seeds of $N$. nucifera was extensively studied in in vitro and in vivo models by many researchers [4, 20-22]. The present study was designed to investigate the effect of $N$. nucifera petal extracts on lipase, adipogenesis, adipolysis, and central receptors in vitro.

\section{Materials and Methods}

2.1. Chemicals. Dexamethasone, isobutylmethylxanthine (IBMX), oil red $\mathrm{O}$, porcine lipase enzyme, thiazolyl blue tetrazolium bromide (MTT), 4-methyl umbelliferyl oleate, GW 803430, melanocyte concentrating hormone (MCH), melanotan II, DL-isoproterenol hydrochloride, and orlistat were procured from Sigma-Aldrich. AM630, CP 55,940, AL34662, cell plating reagent-3, cell assay buffer, substrate reagent 1 , and substrate reagent 2 were obtained from DiscoveRx (USA). Insulin was procured from Biocon. Fetal bovine serum (FBS) and bovine calf serum (BCS) were purchased from Hyclone. Enzychrom glycerol detection kit was procured from BioAssay systems. DMEM was obtained from Gibco Life Technologies.

2.2. Plant Material. The petals of N. nucifera ( $100 \mathrm{~g}$ each) were procured from a local commercial supplier and were authenticated at National Institute of Science Communication and Information Resources (NISCAIR), New Delhi. A voucher specimen (no. 811) was deposited in our herbarium. Dried petals were extracted with methanol $(\sim 400 \mathrm{~mL})$ by refluxing at $70^{\circ} \mathrm{C}$ for 1 hour. Extract solution was filtered, and the remaining raw material was subjected to methanol extraction by repeating the above steps twice. The liquid filtrates were combined and concentrated by distillation under vacuum to a thick paste, followed by drying under vacuum at temperature $70^{\circ} \mathrm{C}$. The dried extract was named as methanol extract and utilized to perform in vitro experiments. Phytochemical investigation of methanol extract of $N$. nucifera was carried out by subjecting methanol extract to HPLC analysis to identify the flavonoids as per the method described by Xingfeng et al. [23].

Methanol extraction of the raw material was carried out as mentioned above. The leftover raw material after methanol extraction was further boiled with water at $85-90^{\circ} \mathrm{C}(3$ times each with 500-600 mL water for $1 \mathrm{~h}$ ) and filtered each time. The liquid filtrates were combined and concentrated by distillation under vacuum to a thick paste, followed by drying under vacuum at temperature $80^{\circ} \mathrm{C}$. The dried extract was named as successive water extract and used to perform in vitro experiments.

2.3. Cell Lines and Culture Conditions. 3T3-L1 cell line was procured from American Type Culture Collection (ATCC). 3T3-L1 fibroblasts were cultured in DMEM supplemented with $10 \% \mathrm{BCS}$ and incubated at $37^{\circ} \mathrm{C} ; 5 \% \mathrm{CO}_{2}$. The U2OS cell line coupled with $5-\mathrm{HT}_{2 \mathrm{C}}$ or $\mathrm{MC}_{4}$ receptor and $\mathrm{CHO}-\mathrm{K} 1$ cell line coupled with $\mathrm{CNR}_{2}$ or $\mathrm{MCHR}_{1}$ receptor were obtained from DiscoveRx. U2OS and CHO-K1 cells were maintained in cell plate reagent in 96-well tissue culture plates for $48 \mathrm{~h}$ and $24 \mathrm{~h}$, respectively.

2.4. Cell Viability Determination. Initial experiments using 3T3-L1, CHO-K1, and U2OS cells were conducted to assess the cytotoxic concentrations of both methanol and successive water extracts of $N$. nucifera. Cell viability was determined by a colorimetric MTT assay as described by Mosmann [24]. In brief, cells were cultured in 96-well plates at a seeding density of $5 \times 10^{3}$ cells/well. After $24 \mathrm{~h}$ of seeding, the cells were treated with and without $N$. nucifera extracts up to a concentration of $100 \mu \mathrm{g} / \mathrm{mL}$. Thereafter, the cells were rinsed and further incubated with MTT for $1 \mathrm{~h}$. After $1 \mathrm{~h}$, MTT crystals were dissolved in $200 \mu \mathrm{L}$ DMSO. Optical density was read at $570 \mathrm{~nm}$, and, consequently, the noncytotoxic concentrations were chosen for conducting in vitro studies.

2.5. Adipogenesis Assay. Effect of N. nucifera petal extracts on adipogenesis was evaluated by examining their ability to inhibit the differentiation of preadipocytes to adipocytes using 3T3-L1 cells as a test system. On day 0 , mouse 3T3L1 fibroblasts were seeded at a density of $3 \times 10^{4}$ cells/well in a 48-well plate containing DMEM supplemented with $10 \%$ BCS. On day 1 , cells were changed to DMEM medium supplemented with FBS (5\%), IBMX (0.5 mM), insulin $(10 \mu \mathrm{g} / \mathrm{mL})$, and dexamethasone $(1 \mu \mathrm{M})$ with and without $N$. nucifera extracts. Guggulsterone was used as a reference control. On day 3, cells were changed to DMEM supplemented with FBS (5\%) and insulin $(5 \mu \mathrm{g} / \mathrm{mL})$ with and without $N$. nucifera petal extracts. On days 5 and 7, the cells were changed to DMEM supplemented with 5\% FBS. On day 8, 3T3-L1 adipocytes were rinsed with PBS and fixed using 10\% formalin for $30 \mathrm{~min}$ followed by another rinse with $60 \%$ isopropanol solution and allowed to dry. The cells were stained with oil red O solution ( $0.5 \%$ oil red $\mathrm{O}$ in isopropanol, diluted in proportion of 3 parts of oil red $\mathrm{O}$ stock and two parts of distilled water) for $15 \mathrm{~min}$ at room temperature. Dye retained in adipocytes was extracted with isopropanol and quantified by measuring the absorbance at $500 \mathrm{~nm}$.

2.6. Adipolysis Assay. Adipolysis assay was performed to evaluate the possible lipolytic activity of $N$. nucifera petal extracts by examining their ability to release glycerol from differentiated 3T3-L1 cells. On day 0, 3T3-L1 cells were seeded at a density of $3 \times 10^{4}$ cells/well in a 48 -well plate containing DMEM medium supplemented with $10 \%$ BCS. On day 1 , cells were changed to DMEM supplemented with 5\% FBS, IBMX $(0.5 \mathrm{mM})$, insulin $(10 \mu \mathrm{g} / \mathrm{mL})$, and dexamethasone $(1 \mu \mathrm{M})$. On day 2, cells were changed to DMEM, supplemented with FBS (5\%) and insulin $(5 \mu \mathrm{g} / \mathrm{mL})$, and left undisturbed for 2 days. On day 4, the cells were allowed to grow in FBS (5\%) for consecutive three days. On day 7, the cells were starved overnight with DMEM containing 2\% BSA. On day 8 , cells were treated with noncytotoxic concentrations of $N$. nucifera extracts and DL-isoproterenol hydrochloride (reference control) separately for $4 \mathrm{hr}$ in KRB (Krebs-Ringer Bicarbonate) buffer ( $\mathrm{pH}$ 7.2). The supernatant was collected and estimated for glycerol content by adding $100 \mu \mathrm{L}$ of 
glycerol working reagent and $10 \mu \mathrm{L}$ of sample/standard per well in a 96-well assay plate. Plate was tapped to mix and incubated at room temperature for $20 \mathrm{~min}$. Read the color intensity at $570 \mathrm{~nm}$ in VersaMax plate reader.

2.7. Lipase Assay. The inhibitory effect of $N$. nucifera on porcine pancreatic lipase was evaluated. The assay was based on the principle of conversion of the substrate 4-methyl umbelliferyl oleate to 4-methyl umbelliferone by an active porcine lipase enzyme [25]. In brief, the total reaction volume of $50 \mu \mathrm{L}$ contained $15 \mu \mathrm{L}$ of Tris buffer/reference control (orlistat)/N. nucifera extract, $5 \mu \mathrm{L}$ of lipase enzyme, $5 \mu \mathrm{L}$ of demineralized water, and $25 \mu \mathrm{L}$ of substrate (4-methyl umbelliferyl oleate). Mix these reagents and determine the change in fluorescence at $25^{\circ} \mathrm{C}$ for $20 \mathrm{~min}$ at an excitation and emission wavelength of $360 \mathrm{~nm}$ and $460 \mathrm{~nm}$, respectively, using FLUOstar Optima.

2.8. Receptor Assays. Both methanol and successive water extracts of petals of $N$. nucifera were screened for possible agonistic and antagonistic activity towards selected receptors at a concentration of $10 \mu \mathrm{g} / \mathrm{mL}$.

\subsubsection{Agonist Assays}

$5 \mathrm{HT}_{2 \mathrm{C}}$ and $\mathrm{MC}_{4} \mathrm{R}$ Receptor Assays. The U2OS cell line coupled with either $5-\mathrm{HT}_{2 \mathrm{C}}$ or $\mathrm{MC}_{4} \mathrm{R}$ receptor was plated at a density of $10^{4}$ cells/well in 96-well tissue culture plates, containing cell plating reagent. After $48 \mathrm{~h}$ incubation, $N$. nucifera petal extracts or reference agonist, (AL34662 for 5$\mathrm{HT}_{2 \mathrm{C}}$; melanotan II for $\mathrm{MC}_{4} \mathrm{R}$ ) were added in separate wells at noncytotoxic concentrations and incubated for $90 \mathrm{~min}$ at $37^{\circ} \mathrm{C} ; 5 \% \mathrm{CO}_{2} .55 \mu \mathrm{L}$ of prepared detection reagent solution was added to each well. After $60 \mathrm{~min}$ incubation at room temperature, the plate was read using luminescence plate reader (FLUOstar).

\subsubsection{Antagonist Assays}

Cannabinoid Receptor $2\left(\mathrm{CNR}_{2}\right)$. Effect of both methanol and successive water extracts of $N$. nucifera on inhibition of CP 55,940 ( $\mathrm{CNR}_{2}$ agonist) elicited $\mathrm{CNR}_{2}$ activity in $\mathrm{Gi} / \mathrm{Go}$ coupled $\mathrm{CHO}-\mathrm{K} 1$ cell line was studied. $10^{4}$ cells/well were plated in 96-well tissue culture plates containing cell plating reagent. After $48 \mathrm{~h}$ incubation, $N$. nucifera or reference antagonist (AM630) was added to the respective wells and incubated for $30 \mathrm{~min}$ at $37^{\circ} \mathrm{C} ; 5 \% \mathrm{CO}_{2} .5 \mu \mathrm{L}$ of agonist compound (CP 55,940) was added to the respective wells in a final volume of $110 \mu \mathrm{L}$ and incubated for $90 \mathrm{~min} .55 \mu \mathrm{L}$ of prepared detection reagent solution was added to each well and incubated for $60 \mathrm{~min}$ at room temperature, and plate was read using luminescence plate reader (FLUOstar).

Melanin Concentrating Hormone Receptor $\left(M C H R_{1}\right)$ Assay. Antagonistic potential of $N$. nucifera extracts on $\mathrm{MCHR}_{1}$ receptor was studied using $\mathrm{MCHR}_{1} \mathrm{Gi}$ coupled $\mathrm{CHO}-\mathrm{K} 1$ cells. Cell density of $3 \times 10^{4}$ cells/well was plated in 96-well tissue culture plates containing cell plating reagent and incubated for $24 \mathrm{~h}$. After incubation, the entire medium was aspirated and $45 \mu \mathrm{L}$ of cell assay buffer and antibody mixture was added to each well. N. nucifera or reference antagonist (GW 803430) was added to the respective wells and incubated for $15 \mathrm{~min}$ at $37^{\circ} \mathrm{C}$ and $5 \% \mathrm{CO}_{2}$. Agonist compound $(\mathrm{MCH}-62.5 \mathrm{nM}+$ Forskolin $20 \mu \mathrm{M}$ ) was added to the respective wells and incubated for $30 \mathrm{~min}$. $60 \mu \mathrm{L}$ of prepared detection reagent solution and cAMP solution D was added to each well and incubated for $60 \mathrm{~min}$ at room temperature in the dark. $60 \mu \mathrm{L}$ of cAMP Solution A was added and incubated for $3 \mathrm{hr}$ at room temperature in the dark. Plate was read using luminescence plate reader (FLUOstar).

2.9. Data Analysis. For adipogenesis and adipolysis assays, statistical analysis was performed by one-way analysis of variance using the Graphpad Prism statistical software. Results are represented as Mean \pm SD from three replicates per treatment group. Differences with $P<0.05$ in comparison to control were considered to be statistically significant. For lipase assay, mean of the relative fluorescence unit (RFU) of $N$. nucifera/reference control tested in triplicate was calculated. From the mean values, percentage inhibition $(\% I)$ was calculated using the following equation:

$$
\% I=\frac{(\text { RFU of Control }- \text { RFU of Sample })}{(\text { RFU of Control })} \times 100 \text {. }
$$

$\mathrm{IC}_{50}$ was calculated by the Finney software. For receptor assays, Student's $t$-test was performed using GraphPad Prism 5 statistical software to test for differences among all treatments. Differences with $P<0.05$ were considered to be significant.

\section{Results}

3.1. Effect of N. nucifera on Differentiation of 3T3-L1 Cells. Noncytotoxic concentrations up to $50 \mu \mathrm{g} / \mathrm{mL}$ and $100 \mu \mathrm{g} / \mathrm{mL}$ were selected for methanol and successive water extract of $N$. nucifera, respectively, for in vitro cell-based assays. To test whether $N$. nucifera extracts inhibit adipocyte differentiation, the differentiated adipocytes were stained by oil red $\mathrm{O}$. The staining results showed that incubation of $N$. nucifera during the differentiation period significantly inhibited 3T3L1 adipogenesis. It was found that treatment of 3T3-L1 cells with $N$. nucifera successive water extract significantly decreased the cell differentiation and lipid accumulation in a dose-dependent manner, compared with control cells. Methanol extract of $N$. nucifera exhibited significant inhibition of adipocyte differentiation by $19 \%$ at a concentration of $2 \mu \mathrm{g} / \mathrm{mL}$. The reference control, guggulsterone, demonstrated a potent inhibitory activity towards lipid accumulation at $20 \mu \mathrm{M}$ with a percentage inhibition of 48 (Figure 1).

3.2. Lipolytic Effect of N. nucifera on Differentiated 3T3-L1 Cells. N. nucifera petal extracts displayed lipolytic activity as evident by significant increase of glycerol release from the differentiated 3T3-L1 cells. Methanol extract of $N$. nucifera showed significant dose-dependent release of glycerol at 


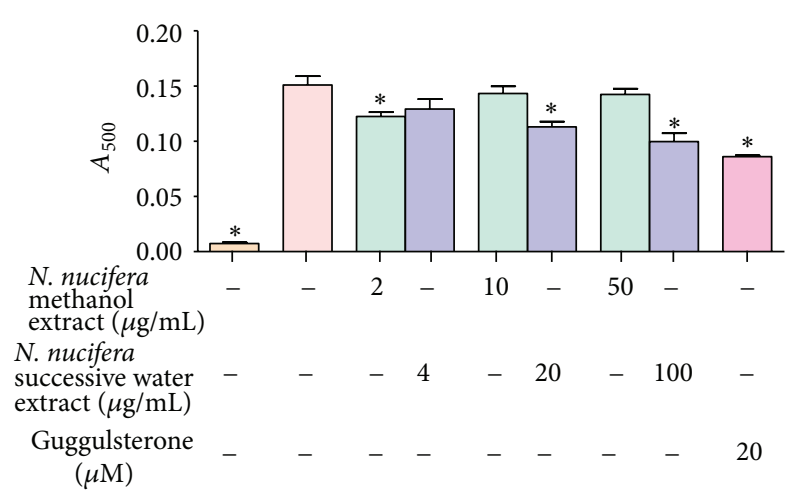

FIGURE 1: Effect of N. nucifera on adipogenesis using 3T3-L1 cells.

concentrations ranging from $2 \mu \mathrm{g} / \mathrm{mL}$ to $50 \mu \mathrm{g} / \mathrm{mL}$. Maximum lipolytic activity of 3.5 -fold increase was observed with methanol extract of $N$. nucifera at a concentration of $50 \mu \mathrm{g} / \mathrm{mL}$. Successive water extract showed significant increase of glycerol levels at highest concentrations (20 and $100 \mu \mathrm{g} / \mathrm{mL}$ ), where a fold increase of 1.9 was observed. Isoproterenol, a known lipolytic agent, elicited a marked glycerol release by fat cells at the tested concentration of $10 \mu \mathrm{M}$ with a 4-fold increase over control (Figure 2).

3.3. Lipase Inhibitory Effect of N. nucifera. Pancreatic lipase inhibition of both methanol and successive water extracts of $N$. nucifera was determined at a screening concentration of $50 \mu \mathrm{g} / \mathrm{mL}$. Percent lipase inhibitory effect of methanol and successive water extract at $50 \mu \mathrm{g} / \mathrm{mL}$ of $N$. nucifera was found to be 52 and 10, respectively. Further, lipase inhibitory potential of methanol extract was tested to determine the $\mathrm{IC}_{50}$ (the concentration required to inhibit a lipase activity by $50 \%)$. Methanol extract of $N$. nucifera exhibited a dosedependent lipase inhibitory effect with an $\mathrm{IC}_{50}$ value of $47 \mu \mathrm{g} / \mathrm{mL}$. However, it was not more effective than orlistat which showed an $\mathrm{IC}_{50}$ value of $26 \mathrm{ng} / \mathrm{mL}$ (Table 1 ).

\subsection{Central Target Action of N. nucifera}

3.4.1. $5-\mathrm{HT}_{2 c}$ and $\mathrm{MC}_{4}$ Receptor Assays. Both methanol and successive water extracts of $N$. nucifera at $10 \mu \mathrm{g} / \mathrm{mL}$ showed significant equipotent stimulatory activity of about 4 -fold increase towards $5-\mathrm{HT}_{2 \mathrm{C}}$ receptor (Table 2). The reference control AL34662 demonstrated a potent dose-dependent agonist activity towards $5-\mathrm{HT}_{2 \mathrm{C}}$ receptor with an $\mathrm{EC}_{50}$ value of $\sim 10.8 \mathrm{nM}$. Both methanol and successive water extracts did not show significant agonist activity towards $\mathrm{MC}_{4}$ receptor at a concentration of $10 \mu \mathrm{g} / \mathrm{mL}$ (Table 2). Melanotan II, a known $\mathrm{MC}_{4} \mathrm{R}$ agonist, demonstrated a concentration-dependent potent agonist activity towards $\mathrm{MC}_{4} \mathrm{R}$ receptor with an $\mathrm{EC}_{50}$ value of $\sim 3.3 \mathrm{nM}$.

3.4.2. $C N R_{2}$ and $M C H R_{1}$ Receptor Assays. At a concentration of $10 \mu \mathrm{g} / \mathrm{mL}$, methanol extract of $N$. nucifera petals displayed $26.2 \%$ antagonism against CP 55,940 activity towards $\mathrm{CNR}_{2}$ receptor, whereas the successive water extract was found to

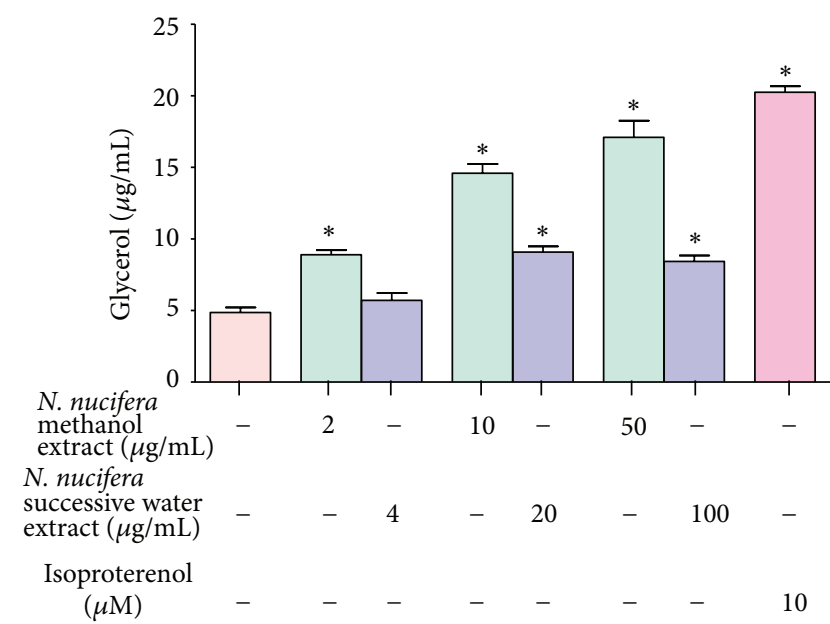

FIGURE 2: Effect of $N$. nucifera on glycerol release from differentiated 3T3-L1 cells.

be inactive at a concentration of $10 \mu \mathrm{g} / \mathrm{mL}$ (Table 2). AM630, a known $\mathrm{CNR}_{2}$ antagonist, demonstrated a potent antagonist activity towards CP 55,940 activated $\mathrm{CNR}_{2}$ receptor with an $\mathrm{IC}_{50}$ value of $\sim 62.3 \mathrm{nM}$. Both of these two extracts did not show antagonist activity towards $\mathrm{MCHR}_{1}$ (Table 2). GW 803430, a known $\mathrm{MCHR}_{1}$ antagonist, demonstrated a potent antagonist activity towards $\mathrm{MCH}$ induced $\mathrm{MCHR}_{1}$ receptor with an $\mathrm{IC}_{50}$ value of $\sim 13 \mathrm{nM}$.

3.5. Phytochemical Analysis of Methanol Extract of N. nucifera. HPLC analysis of crude methanol extract of $N$. nucifera confirmed the presence of flavonoids as major phytochemicals. HPLC followed by UV spectral analysis confirmed the identity of flavonoid glycosides (quercetin and kaempferol glycosides) which is in compliance with the earlier report by Xingfeng et al. [23].

\section{Discussion}

Dietary fat is not directly absorbed by the intestine unless the fat has been subjected to the action of pancreatic lipase. Therefore, pancreatic lipase is one of the most widely studied mechanisms for determining natural products and potential efficacy as antiobesity agents [26]. In this study, we report the inhibitory effects of Nelumbo nucifera petal extracts on pancreatic lipase. Methanol extract elicited an inhibitory effect on lipase enzyme with an $\mathrm{IC}_{50}$ value of $47 \mu \mathrm{g} / \mathrm{mL}$. Similar to our study but on lotus leaf, authors have showed antiobesity activity through a concentration-dependent inhibition of lipase enzyme and also upregulated the lipid metabolism [4]. Nelumbo nucifera is known as sacred lotus and found to have various pharmacologically active substances including alkaloids, flavonoids, triterpenoids, polyphenols, steroids, and glycosides [23]. A phytochemical investigation of $N$. nucifera leaves led to the isolation of eight alkaloids and some of these significantly inhibited pancreatic lipases [20]. Total flavonoids from $N$. nucifera leaves showed high inhibitory 
TABLE 1: Effect of N. nucifera extracts on pancreatic lipase activity.

\begin{tabular}{lcc}
\hline Test sample & Concentration & \% Lipase inhibition \\
\hline & $12.5 \mu \mathrm{g} / \mathrm{mL}$ & 14.78 \\
Nelumbo nucifera & $25 \mu \mathrm{g} / \mathrm{mL}$ & 29.28 \\
methanol extract & $50 \mu \mathrm{g} / \mathrm{mL}$ & 51.81 \\
& $100 \mu \mathrm{g} / \mathrm{mL}$ & 71.94 \\
& $200 \mu \mathrm{g} / \mathrm{mL}$ & 89.87 \\
Nelumbo nucifera & $50 \mu \mathrm{g} / \mathrm{mL}$ & 10 \\
successive water extract & $5 \mathrm{ng} / \mathrm{mL}$ & 28.31 \\
& $10 \mathrm{ng} / \mathrm{mL}$ & 36.89 \\
Orlistat & $25 \mathrm{ng} / \mathrm{mL}$ & 44.88 \\
(reference standard) & $50 \mathrm{ng} / \mathrm{mL}$ & 66.15 \\
& $100 \mathrm{ng} / \mathrm{mL}$ & 68.22 \\
& $200 \mathrm{ng} / \mathrm{mL}$ & 71.91 \\
\hline
\end{tabular}

TABLE 2: Effect of petal extracts of $N$. nucifera on central receptors.

\begin{tabular}{|c|c|c|c|c|c|c|}
\hline \multirow{2}{*}{ Name of the test item } & \multirow{2}{*}{ Solvent } & \multirow{2}{*}{ Concentration } & \multicolumn{4}{|c|}{ RLU (Mean \pm SD) } \\
\hline & & & $5 \mathrm{HT}_{2 \mathrm{C}}$ & $\mathrm{MC}_{4} \mathrm{R}$ & $\mathrm{MCHR}_{1}$ & $\mathrm{CNR}_{2}$ \\
\hline Negative & - & NA & $35947.0 \pm 410.12$ & $2322.3 \pm 111.11$ & NA & NA \\
\hline DMSO & - & $0.1 \%$ & $36188.5 \pm 3324.11$ & $2405.3 \pm 246.41$ & NA & NA \\
\hline $\begin{array}{l}\text { N. nucifera methanol } \\
\text { extract }\end{array}$ & DMSO & $10 \mu \mathrm{g} / \mathrm{mL}$ & $146121.5 \pm 3987.37^{*}$ & $\begin{array}{c}2276.5 \pm 289.21 \\
(\mathrm{NS})\end{array}$ & $\begin{array}{c}321.5 \pm 38.89 \\
(\mathrm{NS})\end{array}$ & $106480.0 \pm 2791.66^{*}$ \\
\hline $\begin{array}{l}\text { N. nucifera successive } \\
\text { water extract }\end{array}$ & DMEM & $10 \mu \mathrm{g} / \mathrm{mL}$ & $150760.5 \pm 15262.89^{*}$ & $\begin{array}{c}2071.5 \pm 282.14 \\
(\mathrm{NS})\end{array}$ & $\begin{array}{c}320.0 \pm 46.67 \\
(\mathrm{NS})\end{array}$ & $\begin{array}{c}122709.0 \pm 6588.82 \\
(\mathrm{NS})\end{array}$ \\
\hline $\begin{array}{l}\text { Agonist AL-34662 } \\
\text { (reference standard) }\end{array}$ & DMSO & $50 \mathrm{~nm}^{*}$ & $136099.9 \pm 2258.78^{*}$ & NA & NA & NA \\
\hline $\begin{array}{l}\text { Agonist melanotan II } \\
\text { acetate salt } \\
\text { (reference standard) }\end{array}$ & DMSO & $950 \mathrm{~nm}^{*}$ & NA & $11798.5 \pm 27.58^{*}$ & NA & NA \\
\hline Agonist CP 55,940 & DMSO & $4.5 \mathrm{~nm}^{1}$ & NA & NA & NA & $144375.5 \pm 7012.38$ \\
\hline Agonist $\mathrm{MCH}$ & DMSO & $62.5 \mathrm{~nm}^{1}$ & NA & NA & $545.0 \pm 1.41$ & NA \\
\hline $\begin{array}{l}\text { Antagonist AM630 } \\
\text { (reference standard) }\end{array}$ & DMSO & $173.2 \mathrm{~nm}^{*}$ & NA & NA & NA & $4025.4 \pm 994.31^{*}$ \\
\hline $\begin{array}{l}\text { Antagonist GW-803430 } \\
\text { (reference standard) }\end{array}$ & DMSO & $18.1 \mathrm{~nm}^{*}$ & NA & NA & $1294.5 \pm 142.13^{*}$ & NA \\
\hline
\end{tabular}

RLU: relative luminescence units; NA: not applicable; ${ }^{*}$ indicates a concentration at which maximum response of reference controls was observed; ${ }^{1}$ indicates $\mathrm{EC}_{80}$ concentration of agonist against which $N$. nucifera petal extracts/reference controls were evaluated for their antagonistic potential.

$P<0.05$.

NS: not significant.

activity against porcine pancreatic lipase, $\alpha$-amylase, and $\alpha$ glucosidase. Also, it lowered total cholesterol, triglycerides, low-density lipoprotein cholesterol, and malondialdehyde and raised the high-density lipoprotein cholesterol in vivo system. Moreover, it alleviated high-fat diet-induced lipid accumulation in the liver [27].

Adipocytes primarily store triglycerides and release them in the form of free fatty acid with the change of energy demand in the body. N. nucifera petal extracts demonstrated significant dose-dependent inhibitory effects on lipid accumulation in 3T3-L1 adipocytes. Alkaloids isolated from $N$. nucifera showed stronger inhibitory effect on adipocyte differentiation [20] and could probably contribute to the activity of petals of $N$. nucifera. Similar to this study but on lotus seed, epicarp extracts of $N$. nucifera were studied using an in vitro 3T3-L1 preadipocyte cell model. Results showed that the lotus seed epicarp extracts inhibited preadipocyte differentiation to adipocyte in a concentration-dependent manner [21]. Antiobesity effect of N. nucifera leaves extract (NNE) using high-fat diet-induced obesity in mice was studied. NNE significantly decreased the high-fat diet-induced weight gain, parametrial adipose tissue weight, and liver triacylglycerol levels in mice. Authors concluded that NNE impaired digestion, inhibited absorption of lipids and carbohydrates, accelerated lipid metabolism, and upregulated energy expenditure [4]. 
In this study, we have demonstrated that the petal extracts of $N$. nucifera clearly exhibit lipolytic activity in a dose-dependent manner in murine 3T3-L1 fibroblasts. Previous studies have reported that a liquid leaf extract of Nelumbo nucifera stimulated lipolysis activity in differentiated adipocytes. Also, authors have showed that treatment of adipocyte cultures with $0.5 \%$ lotus leaf extract solution significantly increased the content of free glycerol. Likewise, cultivation of cells with $1 \%$ lotus leaf extract solution induced a significant release of free glycerol compared to control cells [28]. In another study, 50\% ethanol (EtOH) extract prepared from the leaves of $N$. nucifera stimulated lipolysis in the white adipose tissue (WAT) of mice and possible involvement of beta-adrenergic receptor (beta-AR) pathway was attributed to this effect. $N$. nucifera in preventing dietinduced obesity emerged to be due to various flavonoids and that the activation of beta-AR pathway was involved, at least in part [29].

Based on the $5-\mathrm{HT}_{2 \mathrm{C}}$ receptor study, N. nucifera petal extracts showed significant agonist activity towards $5-\mathrm{HT}_{2 \mathrm{C}}$ receptor and antagonistic activity towards $\mathrm{CNR}_{2}$ indicating its role in central targets of obesity as appetite suppressant. Alkyl 4-hydroxybenzoates were isolated from seeds of $N$. nucifera and shown to enhance and inhibit 5-HT-stimulated inward current (I(5-HT)) mediated by the human 5-HT(3)A receptors expressed in Xenopus oocytes [30]. Similar to this study, Oh et al. [31] demonstrated that chronic treatment with ethanol extract from Morus alba leaves exerts an antiobesity effect in diet-induced obese mice via its direct $\mathrm{MCH}_{1}$ receptor antagonism. Various phytocompounds, namely, alkaloids, anthocyanin, and nonanthocyanin flavonoids, have been isolated from petals of $N$. nucifera $[32,33]$ and shown to have other biological activities; however, their role in antiobesity activity needs to be determined.

Flavonoid-enriched N. nucifera leaf extract significantly inhibited the high-fat diet-induced abnormal blood lipids and liver damage [27]. Galleano et al. [34] consolidated the proof linking flavonoid intake with metabolic disorders, namely, obesity, hypertriglyceridemia, hypercholesterolemia, hypertension, and insulin resistance. However, a number of molecular mechanisms have been identified; the effects of flavonoids on endpoints of metabolic syndrome are still inconclusive. These convolutions were explained by the complex associations among the risk factors of metabolic syndrome, the multiple biological targets controlling these risk factors, and the high number of flavonoids (including their metabolites) present in the diet and potentially responsible for the in vivo effects. As a result, extensive basic and clinical research is warranted to assess the relevance of flavonoids for the treatment of metabolic syndrome [34].

Acute and subchronic oral toxicity studies of $N$. nucifera stamens extract in rats were performed and found to have safety threshold for acute toxicity which is above $5000 \mathrm{mg} / \mathrm{kg}$ bodyweight, and no-observed-adverse-effect level (NOAEL) of the extract for both male and female rats is considered to be $200 \mathrm{mg} / \mathrm{kg} / \mathrm{day}$ [35].

In conclusion, $N$. nucifera petal extract showed antilipase activity, lipolytic and antiadipogenesis effect in adipocytes in vitro. $N$. nucifera extract showed agonist and antagonistic effect towards central receptors involved in food intake. Thus, it is worthwhile to further investigate $N$. nucifera petal extract and phytoconstituents for its potential pharmacological effect in metabolic disorders, in particular obesity.

\section{Conflict of Interests}

All authors declare that they have no conflict of interests.

\section{Acknowledgment}

This research received support from DBT, India, under IndoSpanish joint call for collaboration in the field of biotechnology.

\section{References}

[1] C. V. Chandrasekaran, M. A. Vijayalakshmi, K. Prakash, V. S. Bansal, J. Meenakshi, and A. Amit, "Review: herbal approach for obesity management," American Journal of Plant Sciences, vol. 3, pp. 1003-1014, 2012.

[2] W. La-Ongsri, C. Trisonthi, and H. Balslev, "Management and use of Nelumbo nucifera Gaertn. in Thai wetlands," Wetlands Ecology and Management, vol. 17, no. 4, pp. 279-289, 2009.

[3] M. Kulkarni and A. Juvekar, "Attenuation of acute and chronic restraint stress-induced perturbations in experimental animals by Nelumbo nucifera Gaertn," Indian Journal of Pharmaceutical Sciences, vol. 70, no. 3, pp. 327-332, 2008.

[4] Y. Ono, E. Hattori, Y. Fukaya, S. Imai, and Y. Ohizumi, "Antiobesity effect of Nelumbo nucifera leaves extract in mice and rats," Journal of Ethnopharmacology, vol. 106, no. 2, pp. 238-244, 2006.

[5] S. Rai, A. Wahile, K. Mukherjee, B. P. Saha, and P. K. Mukherjee, "Antioxidant activity of Nelumbo nucifera (sacred lotus) seeds," Journal of Ethnopharmacology, vol. 104, no. 3, pp. 322-327, 2006.

[6] D.-H. Sohn, Y.-C. Kim, S.-H. Oh, E.-J. Park, X. Li, and B. Lee, "Hepatoprotective and free radical scavenging effects of Nelumbo nucifera," Phytomedicine, vol. 10, no. 2-3, pp. 165-169, 2003.

[7] P. K. Mukherjee, K. Saha, J. Das, M. Pal, and B. P. Saha, "Effect of Nelumbo nucifera rhizome extract on blood sugar level in rats," Journal of Ethnopharmacology, vol. 58, no. 3, pp. 207-213, 1997.

[8] P. K. Mukherjee, K. Saha, J. Das, M. Pal, and B. P. Saha, "Studies on the anti-inflammatory activity of rhizomes of Nelumbo nucifera," Planta Medica, vol. 63, no. 4, pp. 367-369, 1997.

[9] P. V. Chakravarthi and N. Gopakumar, "Anti-inflammatory activity of red and white lotus seeds (Nelumbo nucifera) in albino rats," Veterinary World, vol. 3, no. 4, pp. 157-159, 2010.

[10] P. K. Mukherjee, J. Das, K. Saha, S. N. Giri, M. Pal, and B. P. Saha, "Antipyretic activity of Nelumbo nucifera rhizome extract," Indian Journal of Experimental Biology, vol. 34, no. 3, pp. 275276, 1996.

[11] M. Li and $\mathrm{Z}$. Xu, "Quercetin in a lotus leaves extract may be responsible for antibacterial activity," Archives of Pharmacal Research, vol. 31, no. 5, pp. 640-644, 2008.

[12] D. Mukherjee, A. Biswas, S. Bhadra et al., "Exploring the potential of Nelumbo nucifera rhizome on membrane stabilization, mast cell protection, nitric oxide synthesis, and expression of costimulatory molecules," Immunopharmacology and Immunotoxicology, vol. 32, no. 3, pp. 466-472, 2010. 
[13] D. Mukherjee, T. N. Khatua, P. Venkatesh, B. P. Saha, and P. K. Mukherjee, "Immunomodulatory potential of rhizome and seed extracts of Nelumbo nucifera Gaertn," Journal of Ethnopharmacology, vol. 128, no. 2, pp. 490-494, 2010.

[14] P. K. Mukherjee, D. Mukherjee, A. K. Maji, S. Rai, and M. Heinrich, "The sacred lotus (Nelumbo nucifera): phytochemical and therapeutic profile," Journal of Pharmacy and Pharmacology, vol. 61, no. 4, pp. 407-422, 2009.

[15] R. P. Rastogi and B. N. Mehrotra, Compendium of Indian Medicinal Plants, vol. 1 of (1960-1969), pp. 288-289, Central Drug Research Institute, Lucknow and Publications \& Information Directorate, New Delhi, India, 1991.

[16] Y. Huang, L. Zhao, Y. Bai, P. Liu, J. Wang, and J. Xiang, "Simultaneous determination of liensinine, isoliensinine and neferine from seed embryo of Nelumbo nucifera Gaertn. in rat plasma by a rapid HPLC method and its application to a pharmacokinetic study," Arzneimittel-Forschung, vol. 61, no. 6, pp. 347-352, 2011.

[17] B. Xie, J. Wan, W. Wang, C. Shi, X. Hou, and J. Fang, "Nelumbo nucifera alkaloid inhibits 3T3-L1 preadipocyte differentiation and improves high-fat diet-induced obesity and body fat accumulation in rats," Journal of Medicinal Plant Research, vol. 5, no. 10, pp. 2021-2028, 2011.

[18] X. Shuangshuang, D. Wenjuan, F. Lei, S. Yu, D. Hongjing, and W. Xiao, "Isolation and characterization of chemical constituents from the petals of Nelumbo nucifera," Asian Journal of Chemistry, vol. 24, pp. 4619-4622, 2012.

[19] C. Wu, M. Yang, K. Chan, P. Chung, T. Ou, and C. Wang, "Improvement in high-fat diet-induced obesity and body fat accumulation by a Nelumbo nucifera leaf flavonoid-rich extract in mice," Journal of Agricultural and Food Chemistry, vol. 58, no. 11, pp. 7075-7081, 2010.

[20] J. H. Ahn, E. S. Kim, C. Lee et al., "Chemical constituents from Nelumbo nucifera leaves and their anti-obesity effects," Bioorganic and Medicinal Chemistry Letters, vol. 23, no. 12, pp. 3604-3608, 2013.

[21] S. Qi and D. Zhou, "Lotus seed epicarp extract as potential antioxidant and anti-obesity additive in Chinese Cantonese Sausage," Meat Science, vol. 93, no. 2, pp. 257-262, 2013.

[22] J. S. You, Y. J. Lee, K. S. Kim, S. H. Kim, and K. J. Chang, "Antiobesity and hypolipidemic effects of Nelumbo nucifera seed ethanol extract in human preadipocytes and rats fed a high-fat diet," Journal of the Science of Food and Agriculture.

[23] G. Xingfeng, W. Daijie, D. Wenjuan, D. Jinhua, and W. Xiao, "Preparative isolation and purification of four flavonoids from the petals of Nelumbo nucifera by high-speed counter-current chromatography," Phytochemical Analysis, vol. 21, no. 3, pp. 268$272,2010$.

[24] T. Mosmann, "Rapid colorimetric assay for cellular growth and survival: application to proliferation and cytotoxicity assays," Journal of Immunological Methods, vol. 65, no. 1-2, pp. 55-63, 1983.

[25] US patent publication number: US, 2008/0317821 A1, dated December 2008.

[26] R. B. Birari and K. K. Bhutani, "Pancreatic lipase inhibitors from natural sources: unexplored potential," Drug Discovery Today, vol. 12, no. 19-20, pp. 879-889, 2007.

[27] S. Liu, D. Li, B. Huang, Y. Chen, X. Lu, and Y. Wang, "Inhibition of pancreatic lipase, $\alpha$-glucosidase, $\alpha$-amylase, and hypolipidemic effects of the total flavonoids from Nelumbo nucifera leaves," Journal of Ethnopharmacology, vol. 149, pp. 263-269, 2013.
[28] R. Siegner, S. Heuser, U. Holtzmann et al., "Lotus leaf extract and L-carnitine influence different processes during the adipocyte life cycle," Nutrition and Metabolism, vol. 7, article 66, 2010.

[29] E. Ohkoshi, H. Miyazaki, K. Shindo, H. Watanabe, A. Yoshida, and H. Yajima, "Constituents from the leaves of Nelumbo nucifera stimulate lipolysis in the white adipose tissue of mice," Planta Medica, vol. 73, no. 12, pp. 1255-1259, 2007.

[30] U. J. Youn, J. Lee, Y. J. Lee, J. W. Nam, H. Bae, and E. Seo, "Regulation of the 5-HT3A receptor-mediated current by alkyl 4-hydroxybenzoates isolated from the seeds of Nelumbo nucifera," Chemistry and Biodiversity, vol. 7, no. 9, pp. 22962302, 2010.

[31] K. Oh, S. Y. Ryu, S. Lee et al., "Melanin-concentrating hormone1 receptor antagonism and anti-obesity effects of ethanolic extract from Morus alba leaves in diet-induced obese mice," Journal of Ethnopharmacology, vol. 122, no. 2, pp. 216-220, 2009.

[32] S. Chen, Y. Xiang, J. Deng, Y. Liu, and S. Li, "Simultaneous analysis of anthocyanin and non-anthocyanin flavonoid in various tissues of different lotus (Nelumbo) cultivars by HPLCDAD-ESI-MS(n)," Public Library of Science One, vol. 8, no. 4, Article ID e62291, 2013.

[33] S. Nakamura, S. Nakashima, G. Tanabe et al., "Alkaloid constituents from flower buds and leaves of sacred lotus (Nelumbo nucifera, Nymphaeaceae) with melanogenesis inhibitory activity in B16 melanoma cells," Bioorganic Medicinal Chemistry, vol. 21, no. 3, pp. 779-787, 2013.

[34] M. Galleano, V. Calabro, P. D. Prince et al., "Flavonoids and metabolic syndrome," Annals of the New York Academy of Sciences, vol. 1259, pp. 87-94, 2012.

[35] P. Kunanusorn, A. Panthong, P. Pittayanurak, S. Wanauppathamkul, N. Nathasaen, and V. Reutrakul, "Acute and subchronic oral toxicity studies of Nelumbo nucifera stamens extract in rats," Journal of Ethnopharmacology, vol. 134, no. 3, pp. 789-795, 2011. 


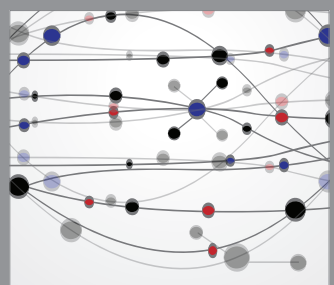

The Scientific World Journal
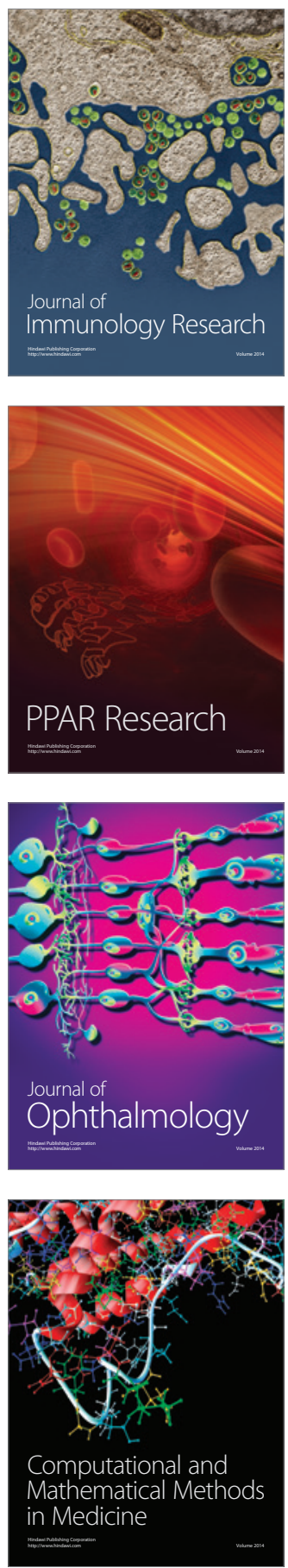

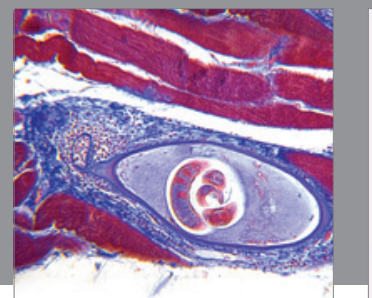

Gastroenterology

Research and Practice
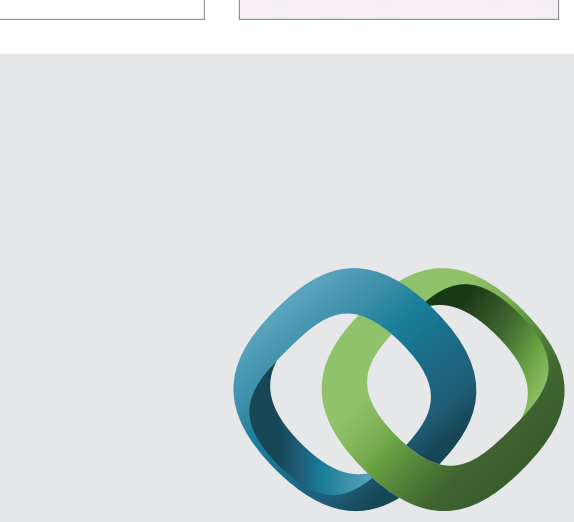

\section{Hindawi}

Submit your manuscripts at

http://www.hindawi.com
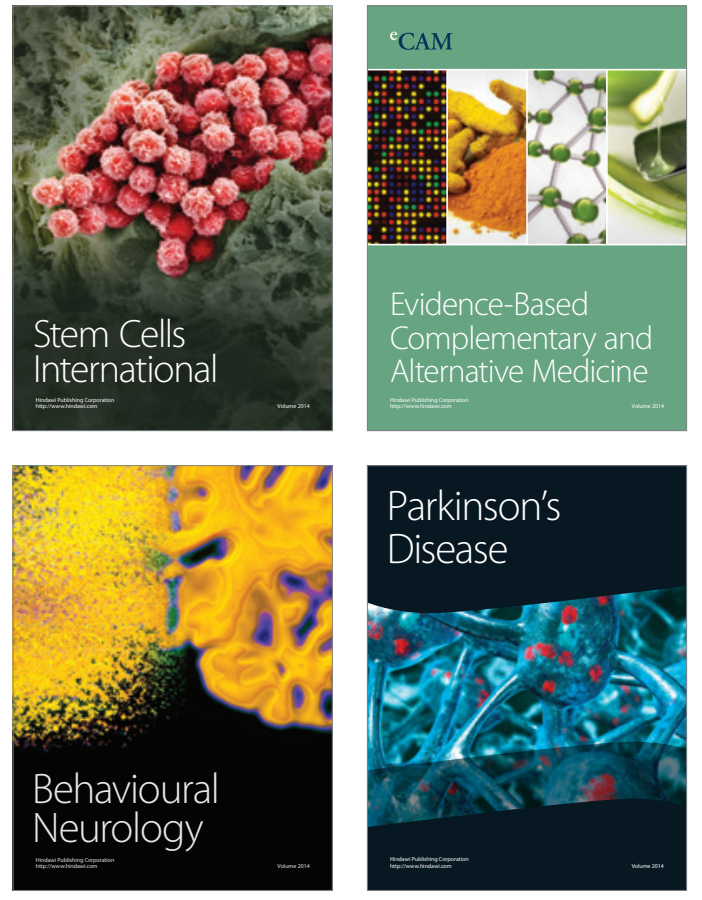
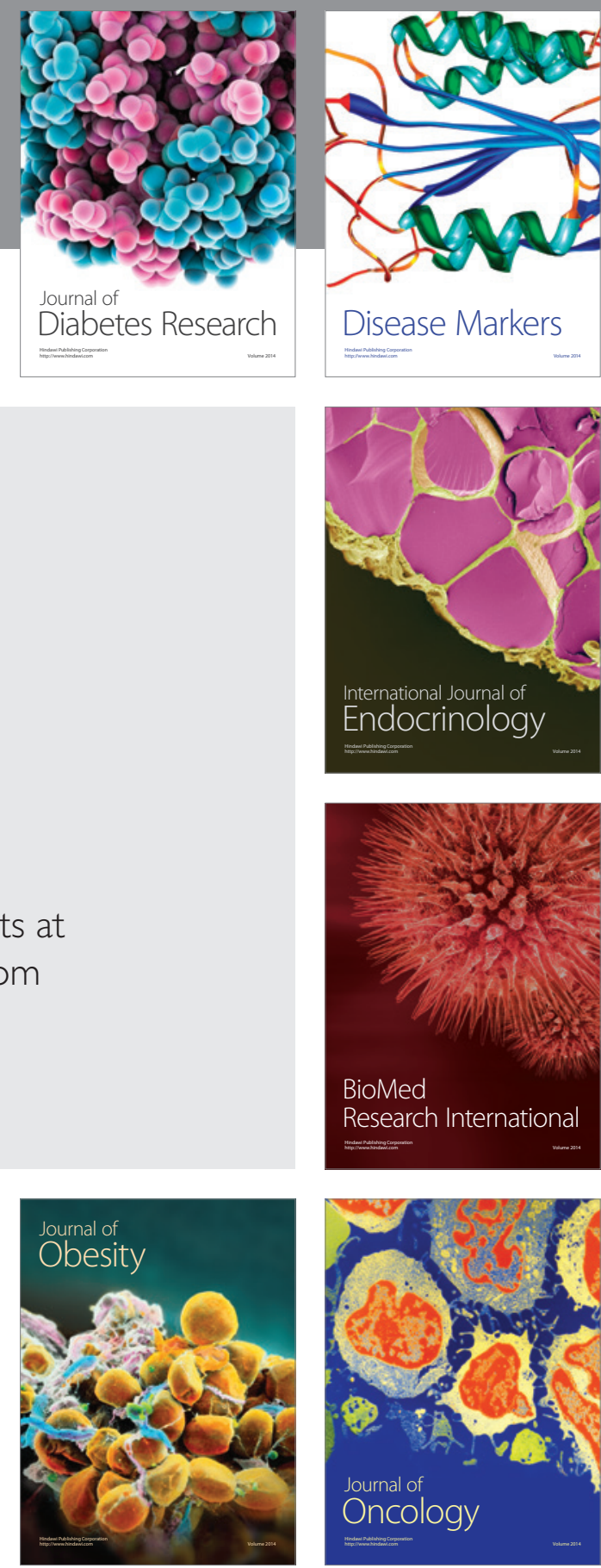

Disease Markers
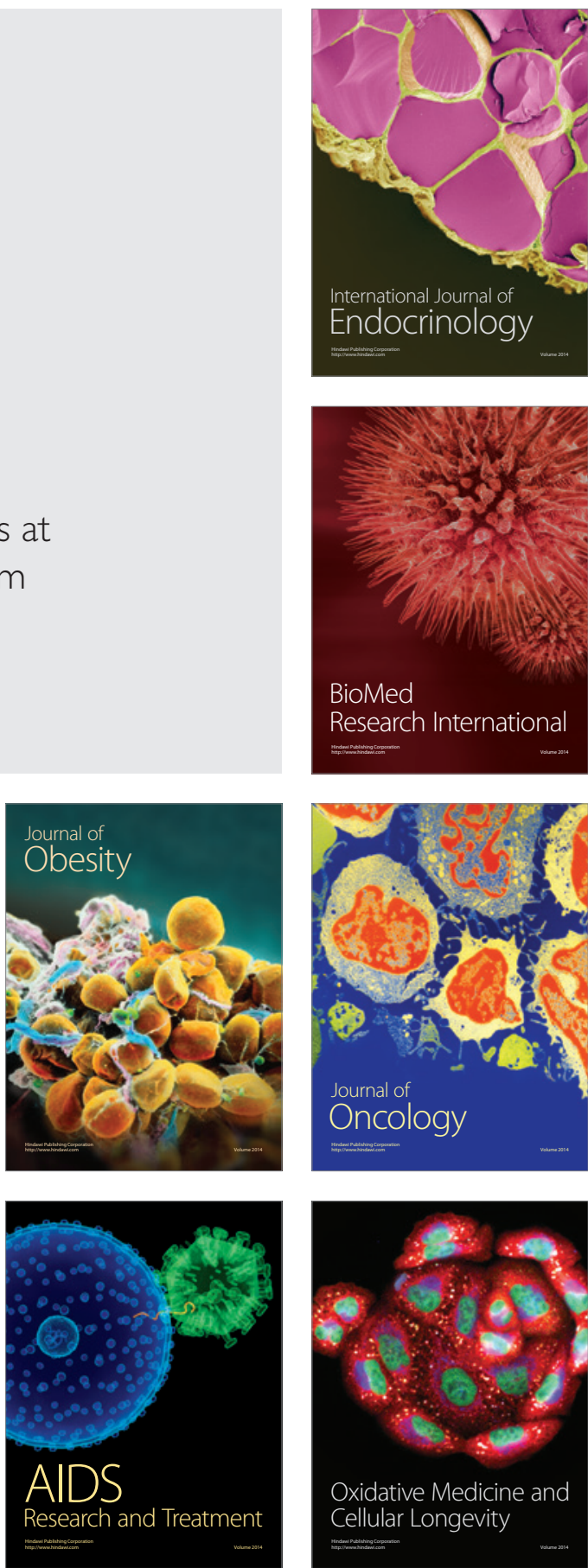